\title{
Ethical dilemmas in the face of the possibility of suffering from Alzheimer's disease or other dementias. An exploratory study
}

Asunción Álvarez-del Río ${ }^{* *}$ and Ma. Luisa Marván²

${ }^{1}$ Department of Psychiatry and Mental Health, Faculty of Medicine, Universidad Nacional Autónoma de México, Mexico City; ${ }^{2}$ Institute of Psychological Research, Universidad Veracruzana, Veracruz. Mexico

\begin{abstract}
Introduction: In Mexico, efforts have been made to increase understanding of Alzheimer's disease (AD) and other dementias, as well as to improve the care of patients with these diseases and that of their caregivers. However, people's interest in making decisions and facing the ethical dilemmas regarding the possibility of living with mental diseases has not been investigated. Objective: To know the opinions of mature adults on some ethical dilemmas related to the possibility of living with $A D$ or other dementias. Methods: Observational, cross-sectional, correlational study. Participants answered a self-administered questionnaire. Results: 134 mature adults answered the questionnaire; $70.9 \%$ had thought about the possibility of suffering from some dementia and the vast majority would like to know their diagnosis; approximately, half the participants had informed their families of their wishes about medical treatment in the future; $39.6 \%$ did not approve artificially feeding a patient who can no longer eat or decide; $37.3 \%$ did approve this. Conclusions: There is interest in advance decisions in the face of the possibility of suffering from dementia. To answer unanswered questions in this regard, it is important for research on the subject to continue, as well as to solve some ethical dilemmas and promote the use of advance directives.
\end{abstract}

KEY WORDS: Alzheimer's disease. Dementia. Mature adults. Ethical dilemmas.

\section{Dilemas éticos ante la posibilidad de padecer la enfermedad de Alzheimer u otras demencias. Estudio exploratorio}

\section{Resumen}

Introducción: En México se han realizado esfuerzos para incrementar la comprensión de la enfermedad de Alzheimer y otras demencias, así como para mejorar la atención de los pacientes con estas enfermedades y la de sus cuidadores. Sin embargo, no se ha investigado el interés de las personas por la toma de decisiones ante la posibilidad de vivir con dichas enfermedades y enfrentar los dilemas éticos implicados. Objetivo: Conocer las opiniones de adultos maduros sobre algunos dilemas éticos ante la posibilidad de vivir con enfermedad de Alzheimer u otras demencias. Métodos: Estudio observacional, transversal y correlacional. Los participantes contestaron un cuestionario autoaplicable. Resultados: 134 adultos maduros respondieron el cuestionario; 70.9 \% había pensado en la posibilidad de padecer alguna demencia y la mayoría desearía conocer su diagnóstico, aproximadamente la mitad comunicó a sus familiares su voluntad sobre tratamientos médicos en el futuro, $39.6 \%$ no aprobaba alimentar artificialmente a un paciente que no puede comer ni decidir y $37.3 \%$ sí lo aprobaba. Conclusiones: Hay interés en las decisiones anticipadas ante la posibilidad de padecer demencia. Para responder a las interrogantes al respecto es importante continuar investigando sobre el tema, así como para resolver algunos dilemas éticos y promover el uso de la voluntad anticipada.

PALABRAS CLAVE: Enfermedad de Alzheimer. Demencia. Adultos maduros. Dilemas éticos.

\footnotetext{
Correspondence:

Date of reception: 22-11-2020

*Asunción Álvarez-del Río

Date of acceptance: 10-02-2021

E-mail: asun57@gmail.com

DOI: 10.24875/GMM.M21000582

Gac Med Mex. 2021;157:404-410

Contents available at PubMed license (http://creativecommons.org/licenses/by-nc-nd/4.0/).
} 


\section{Introduction}

Improvement of health services and major scientific and technological breakthroughs have allowed to considerably increase life expectancy, but many people live in a situation of dependency that is considered undignified, as it occurs with Alzheimer's disease (AD), the most common form of dementia. Like other dementias, it causes a progressive decline in cognitive functions, deterioration of emotional control and social behaviour, which destroy personality, relationships and the ability to decide. ${ }^{1} \mathrm{AD}$, like other dementias, is a condition that some people fear more than cancer. $^{2}$

AD can occur at any age once adulthood has been reached, but most commonly at old age; given the population aging, increasingly more people are likely to suffer from it. ${ }^{3}$ According to the World Health Organization, in 2019 there were 50 million people with dementia in the world. ${ }^{4}$ In Mexico, estimates indicate that, by 2050 , there will be 3.5 million older adults with some dementia. ${ }^{5}$ The probability of suffering from $A D$ after surpassing 65 years of age is one in every 20 individuals; in those older than 80 , one in five. ${ }^{3}$

Three stages have been established for AD: mild, moderate, and severe. During the first one, the patient continues to carry out activities and make decisions; in the moderate stage, the individual is incapable of selfcare, which increases dependency; in severe disease, deterioration and dependency are complete, and psychological characteristics of the individual are lost. ${ }^{6} \mathrm{AD}$ duration can range between 7 and 10 years, but there are patients who live longer. As with other dementias, $A D$ cannot be cured and only its progression can be delayed.

AD diagnosis is essentially clinical based on cognitive impairment, once other causes have been ruled out. Neuroimaging studies and biomarkers support the diagnosis, which is conclusive with histopathological examination after death. ${ }^{1}$ Dementia early diagnosis is a good opportunity for generating an advance directive document, since the person still preserves the capacity to decide. ${ }^{7}$

In Alzheimer's Disease International most recent report, the results of a survey that included almost 70 thousand people (general public, health professionals, patients and caregivers) from 155 countries are described. Almost 95\% thought they could develop dementia and $78 \%$ feared this disease; $85 \%$ of people with dementia said that their opinion about their care was not taken into account. ${ }^{8}$

Genetically-determined AD cases are a minority. ${ }^{9}$ Other factors appear to influence on the onset of the disease such as cerebrovascular disease, high blood pressure, type 2 diabetes, overweight and cholesterol. ${ }^{10}$ Some protective factors have also been identified: diet, physical activity and cognitive exercises. ${ }^{11}$ While some people acquire habits to prevent $A D$, others trust that treatments will be discovered to prevent or cure $i^{12}$ and others want to be in control if they fall ill.

Advance Care Planning and advance directives documents have been reported in people who do not want to live with advanced dementia. ${ }^{13,14}$ In Mexico, an advance directive document can be signed stating legal decisions such as discontinuation (or non-initiation) of treatments that prolong life and request palliative care..$^{15}$

In Mexico, important efforts have been made on dementia research and for the care of patients and their caregivers, ${ }^{3,16}$ considering the principles and ethical dilemmas involved; ${ }^{1}$ however, the interest of people about making decisions when considering the possibility of living with dementia has not been investigated. We started a line of research in order to study this aspect, whereby we hope to contribute to the discussion about the decisions concerning the care and treatment of patients at advanced stages.

The purpose of this first study was to know the opinions of mature adults about the interest in knowing their diagnosis if they suffer from dementia, and about artificial nutrition and hydration for the patients at advanced stage, as well as to know if they have communicated their wishes regarding future treatments in advance.

\section{Methods}

The ethics and research commissions of the National Autonomous University of Mexico Faculty of Medicine approved this study.

The sample comprised 134 mature adults from Mexico City with college education. Most were recruited at public places and others at day care homes for seniors. The inclusion criterion was being aged between 50 and 75 years, knowing that $A D$ is characterized by gradual memory loss and that it is a progressive disease with no cure (participants were asked what they knew about $A D$ ). The exclusion criterion was having a diagnosis of dementia or having any physical 
Table 1. Participants' sociodemographic characteristics

\begin{tabular}{|c|c|c|}
\hline \multirow[t]{2}{*}{ Age in years, mean \pm SD } & \multicolumn{2}{|c|}{$59.9 \pm 7.8$} \\
\hline & $n$ & $\%$ \\
\hline $\begin{array}{l}\text { Gender } \\
\text { Females } \\
\text { Males }\end{array}$ & $\begin{array}{l}82 \\
52\end{array}$ & $\begin{array}{l}61.2 \\
38.8\end{array}$ \\
\hline $\begin{array}{l}\text { Religion } \\
\text { Catholic or Christianism-derived } \\
\text { Other } \\
\text { None }\end{array}$ & $\begin{array}{c}109 \\
3 \\
22\end{array}$ & $\begin{array}{c}81.3 \\
2.2 \\
16.4\end{array}$ \\
\hline $\begin{array}{l}\text { Religiosity } \\
\text { Highly important } \\
\text { Important } \\
\text { Slightly important } \\
\text { Unimportant }\end{array}$ & $\begin{array}{l}30 \\
48 \\
31 \\
23\end{array}$ & $\begin{array}{l}22.7 \\
36.4 \\
23.5 \\
17.4\end{array}$ \\
\hline $\begin{array}{l}\text { Lives with } \\
\text { Partner } \\
\text { Partner and children } \\
\text { Children } \\
\text { Alone } \\
\text { Other relative } \\
\text { Caregiver }\end{array}$ & $\begin{array}{c}34 \\
41 \\
21 \\
22 \\
14 \\
1\end{array}$ & $\begin{array}{c}25.4 \\
30.6 \\
15.7 \\
16.4 \\
10.4 \\
0.7\end{array}$ \\
\hline
\end{tabular}

or mental condition that compromised their understanding ability. The rate of acceptance was $92 \%$.

The participants granted informed consent and answered a questionnaire developed for this research and previously tested. In addition to some sociodemographic data, the following was explored:

- If participants knew someone close who suffered from $A D$ or other dementias and if they were directly involved in their care

- If they had thought about the possibility of suffering from $A D$ or other dementias

- If they wanted to know the diagnosis with answer options "yes," "no," "I am not sure," with a justification for their answer

- If their families knew their wishes about their treatments in case they suffer from another disease and would not be able to decide due to dementia

- Whether or not they agreed with artificial nutrition and hydration for patients with $A D$ or other dementias without the ability to decide. Again, the answer options were "yes," "no," "I am not sure," with a justification for the answer.

Contingency tables were generated with the chisquare test in order to know the association between variables (significant results with a $p$-value $\leq 0.05$ ), as well as a content analysis of the open questions in order to generate categories. Reliability was between 0.84 and 1 using Cohen's kappa index.

\section{Results}

One hundred and thirty-four individuals aged between 50 and 77 years were surveyed. Table 1 describes their sociodemographic characteristics. Half the participants $(n=68)$ knew someone close with dementia; out of them, $37.3 \%(n=25)$ were directly involved in his/her care. Most participants ( $\mathrm{n}=95,70.9 \%$ ) had thought about the possibility of suffering from $A D$ or other dementias; among them, the majority ( $n=56,58.9 \%$ ) referred knowing someone close who had suffered from dementia. Conversely, most of those who had not thought about it $(n=27,69.2 \%)$ did not know anyone close with dementia (statistically significant results, $\chi^{2}=$ 7.69, $p=0.006$ ).

When asked if they would like to know the diagnosis in case of suffering from dementia, the vast majority answered affirmatively ( $n=126,94 \%)$. Among the remaining eight surveyed subjects, five answered no and three were not sure. Table 2 shows the categories the explanations were classified in. The most common answer about wanting to know their diagnosis was "for preparing," followed by "decision-making" and "search for therapeutic options." The main amswer for not wanting to know or not being sure was "painful."

Among the participants, $50.7 \%$ assured that their relatives know their wishes in case of suffering from advanced stage dementia and that they will have to decide about their treatments; $88.1 \%$ of them $(n=59)$ said that their families know about their wishes through talks; $6 \%(n=4)$ had a notarized advance directives document; the rest had an unofficial document.

Regarding the opinion of participants about artificially feeding and hydrating patients with dementia who can no longer eat and lack the ability to decide, $39.6 \%(n=53)$ disagreed, while $38.8 \%(n=52)$ agreed and the rest was not sure. Table 3 shows the explanations' categories. The percentage of subjects who agreed was similar to that of individuals who did not. Most of those who agreed consider that "it is a duty;" the answer of those who disagreed was "therapeutic futility." For most subjects who were not sure, it would depend on the "wishes of the patient."

There were no significant associations between agreeing and disagreeing with artificial nutrition and 
Table 2. Reasons why participants would like or not to be communicated their diagnosis of Alzheimer's disease or other dementia

\begin{tabular}{|c|c|c|c|}
\hline Answer category & $\mathrm{n}$ & $\%$ & Answer example \\
\hline \multicolumn{4}{|c|}{ Participants who would like to know their diagnosis } \\
\hline $\begin{array}{l}\text { It is a right } \\
\text { Answers that denote the demand of what is considered ethically } \\
\text { deserved }\end{array}$ & 9 & 7.4 & $\begin{array}{l}\text { Because everyone has the right to know what } \\
\text { occurs in their body }\end{array}$ \\
\hline $\begin{array}{l}\text { To prepare } \\
\text { Answers that indicate that they would like to know the diagnosis in } \\
\text { order to take actions or seek optimal psychological conditions to } \\
\text { confront the disease }\end{array}$ & 38 & 31.1 & $\begin{array}{l}\text { To psychologically prepare and receive support } \\
\text { from the family }\end{array}$ \\
\hline $\begin{array}{l}\text { Search for therapeutic options } \\
\text { Answers that express interest in knowing the diagnosis in order to have } \\
\text { the opportunity to receive therapeutic help that improves their quality of } \\
\text { life and slows disease progression. Some answers refer to deterioration } \\
\text { prevention }\end{array}$ & 28 & 23.0 & $\begin{array}{l}\text { To take care and look after myself. Because I } \\
\text { could fight to reduce the damage as much as } \\
\text { possible }\end{array}$ \\
\hline $\begin{array}{l}\text { Decision making } \\
\text { Answers that indicate interest in knowing the diagnosis in order for } \\
\text { them to be the ones who define how they want to be treated when they } \\
\text { can no longer express their wishes }\end{array}$ & 29 & 23.8 & To be able to decide about my future \\
\hline $\begin{array}{l}\text { Understanding of the situation } \\
\text { Answers that express interest in living with the knowledge and } \\
\text { understanding of what the disease entails }\end{array}$ & 15 & 12.3 & To know what is happening \\
\hline $\begin{array}{l}\text { To make the most of time } \\
\text { They would like to know the diagnosis in order to make the most of the } \\
\text { life time they would have left before deteriorating by the disease }\end{array}$ & 3 & 2.5 & To do the things I want to do before I leave \\
\hline Total & 122 & 100 & \\
\hline \multicolumn{4}{|c|}{ Participants who would not like to know their diagnosis or who are not sure if they want to know or not } \\
\hline $\begin{array}{l}\text { Painful } \\
\text { Answers that express that they would not want to know because it } \\
\text { would cause them much distress }\end{array}$ & 5 & 71.4 & What for? It is too sad \\
\hline $\begin{array}{l}\text { Negation } \\
\text { Answers denoting that they would rather live as if they were not ill }\end{array}$ & 2 & 28.6 & It is better not knowing those things and enjoy \\
\hline Total & 7 & 100 & \\
\hline
\end{tabular}

hydration and the fact of knowing someone close with dementia or having participated in his/her care.

\section{Discussion}

This first study of a line of research explores the opinions of mature adults about some ethical dilemmas regarding the care of people with dementia and the interest in maintaining control in case of suffering from $A D$ or other dementias; it is also the first one to address this aspect in Mexico. It focused on mature adults aged between 50 and 75 years.

Given that age increases the likelihood of suffering from dementia, it is not surprising that approximately half the participants knew someone close with $A D$ or other dementias. This may have influenced on the fact that most of them thought about the possibility of suffering from it, although in a lower percentage (70.9\%) than that of Alzheimer's Disease International recent world report (95\%). ${ }^{8}$ In our study, the majority of those who had not thought about the possibility of suffering from it did not know anyone close with dementia.

Thinking about the possibility suffering from dementia leads to wonder about how to live without being able to decide, about dignity and agreements with family members before becoming incompetent. ${ }^{17}$ Some people want to act if they suffer from it, but they need to know their diagnosis. Most participants would like to know it in order to prepare for confronting dementia, receive therapeutic help in order to improve 
Table 3. Reasons why participants agree or disagree with artificial nutrition and hydration for patients with dementia who no longer have the ability to decide

\begin{tabular}{|c|c|c|c|}
\hline Answer category & n & $\%$ & Answer example \\
\hline \multicolumn{4}{|c|}{ Participants who disagreed with artificial hydration and nutrition } \\
\hline $\begin{array}{l}\text { Therapeutic futility } \\
\text { When they consider that artificial hydration and nutrition lack therapeutic utility }\end{array}$ & 32 & 60.4 & If there is no other choice left, better not \\
\hline $\begin{array}{l}\text { To avoid further suffering } \\
\text { Answers that express the desire to minimize the suffering of both patients } \\
\text { and family members }\end{array}$ & 12 & 22.6 & $\begin{array}{l}\text { Because it is only prolonging patient agony } \\
\text { and that of the people around him }\end{array}$ \\
\hline $\begin{array}{l}\text { Stop being a burden } \\
\text { When they consider that there is no point in maintaining the life of someone } \\
\text { whose care falls completely on others }\end{array}$ & 6 & 11.3 & $\begin{array}{l}\text { It would mean being } 100 \% \text { under the care of } \\
\text { a family member }\end{array}$ \\
\hline $\begin{array}{l}\text { It is unnatural } \\
\text { When they consider that the procedure should not be used because it is an } \\
\text { artificial prolongation of life }\end{array}$ & 3 & 5.7 & Depending on a machine is not normal \\
\hline Total & 53 & 100 & \\
\hline
\end{tabular}

Participants who agree with artificial hydration and nutrition

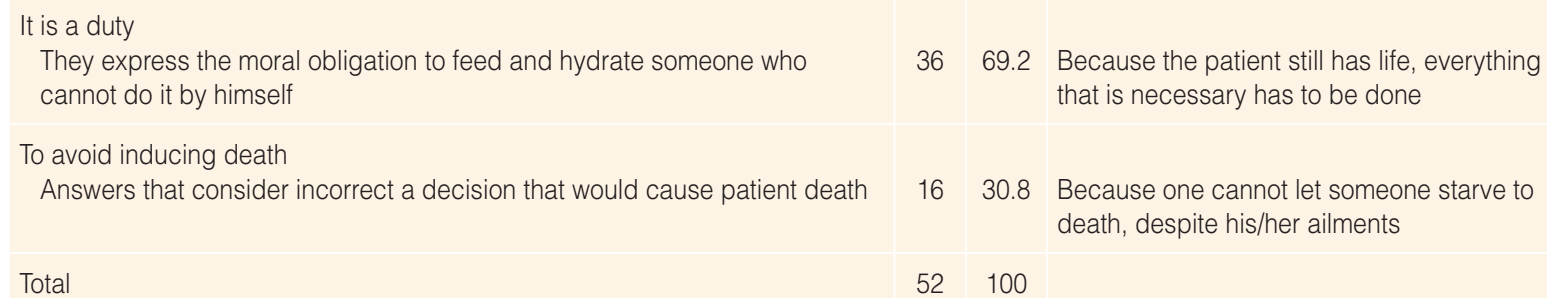

Participants who are not sure whether or not they agree with artificial hydration and nutrition

Patient wishes

When they indicate that the decision should be based on what the patient has expressed he/she would want

Depends on family and patient wishes

When they believe that both what the patient has expressed at the time and

the opinion of the relatives in charge of him/her should be taken into account

Uncertainty
Answers that denote doubts about whether the measure is adequate or not

Ambivalence

Answers that denote both a positive and a negative assessment of artificial hydration and nutrition

Total
1344.8 It depends on what this person has decided prior to the disease

$6 \quad 20.7$ It depends on what the person decides before reaching the point of not remembering and on family resolutions

931.0 I do not know, it depends on whether it would harm or benefit

13.4 Because the person should continue living, but I do not completely agree because one should die in peace

$29 \quad 100$ their quality of life, and decide on future treatments. A minority did not want to know or was not sure in order for not getting upset.

Given that, in dementias, cognitive impairment gradually increases, diagnosed people know that they will lose their ability to decide. Doctors must truthfully inform them in order for them to be able to make arrangements for their future, even if family members ask otherwise. ${ }^{1,13}$ However, according to Alzheimer's Disease International world report, $35 \%$ of caregivers in the world have concealed the diagnosis. ${ }^{8}$ Although control of the patient over his life involves various aspects (financial, testamentary), this study focused on medical care. Patients should communicate what they want in 
the future; although doctors and family members seek the best for the patient, their values can lead them to decide interventions that are contrary to him/her.

Half the participants had communicated their wishes about future treatments to their families through talks; very few through an official advance directives document that allows refusing life-prolonging treatments when, in addition to suffering from dementia, suffer from a life-threatening disease. Although the advance directives document is intended for advanced stages of dementia, it could be applied at moderate stages if the person thus decides.

The opinion about artificial nutrition and hydration in patients with dementia who are unable to eat or decide was explored. The frequency of answers of agreement and disagreement was similar. Given that feeding has a strong social value, many relatives feel that they cannot let their patient die, which is why artificial nutrition is frequently requested by family members and also decided by doctors, despite reports indicating that enteral nutrition does not benefit patients with advanced dementia: it does not increase survival and can cause harm (aspiration and development of ulcers). ${ }^{18}$ Given that neurobiological structures are affected at very advanced stages of the disease, thirst, hunger or associated suffering are not experienced. ${ }^{19}$

The reasons of those who disagreed with providing artificial nutrition and hydration are consistent with medical evidence that parenteral nutrition is not indicated and that it would be therapeutic futility; in addition, they considered that not providing it avoids additional suffering, it ceases to be a burden and that it is unnatural. Those who expressed their opinion in this direction could be influenced by the idea of finding themselves in this situation and not wanting to prolong the suffering of the family or being a burden. The main reason for agreeing with artificial nutrition was for considering that it is a duty to feed those who cannot do it by themselves, which is an argument that agrees with the Catholic hierarchy, which considers nutrition and hydration as normal care and that their withdrawal is equivalent to euthanasia. The other reason was not inducing patient death, an idea that assumes that it is always better to live longer and that is related to the principle of sanctity of life that forbids bringing about death. ${ }^{20}$ The main explanation of those who were not sure was that it should be a patient decision, which reinforces the importance of advance directives and their dual function: that people trust that their wishes will be respected when they can no longer express them and to facilitate family decisions on their behalf.
Recognizing the usefulness of advance directives, there are controversies regarding their use in patients with advanced dementia:

- Many people consider more important not to live with dementia than preventing suffering or indignity for a few months at the end of life. They do not want to be dependent or a burden. With no other life-threatening disease, the treatments of which they might reject in order to die, they are forced to live ${ }^{14}$

- Some people are not only afraid of living with dementia, but that their advance directives will not be respected in the medical institution, as in fact it has occurred

- It may happen that a person documents his/her advance directives in order for not to live in an advanced state of dementia, and when reaching it, not to suffer and even enjoy some experiences. ${ }^{21}$

A distinction has been made between critical values that express personal interests, such as the idea of a dignified life, and those that are purely experiential. ${ }^{22}$ When writing an advance directives document, it should be made clear that refusing treatment (and dying) is desired, even if one appears to be happy, ${ }^{21}$ because the fundamental idea is not to live when one has forgotten who he/she is. This raises the ethical dilemma of whether the wishes of the person who was competent should prevail over the life of the currently incompetent person, a problem that some philosophers have called "the someone else problem." ${ }^{23}$ There is much that remains to be discussed for deciding how to answer to people's interest in having control over their lives if they suffer from $A D$ or other dementias through advance directives.

\section{Conclusions}

This study confirms the interest of a group of mature adults in making early decisions when considering the possibility of suffering from dementia, the importance of research on the topic to continue in order to respond to this interest, solve some ethical dilemmas and promote the advance directives document.

The findings should be interpreted within the context of their limitations and suggestions for future studies. First, the sample was made up of people with a college degree or higher education level; a sample with different education levels would enable for it to be representative of the Mexican population. Second, the percentage of participants who had communicated their wishes about 
future treatments and their opinion about decisions that are legal in our country was explored. In future studies, it would be interesting asking opinions about assisted death and about the decision to stop eating and drinking that has been documented in other countries.

\section{Conflict of interests}

The authors declare that there are no potential conflicts of interest with regard to the research.

\section{Funding}

No financial support was received for the research.

\section{Ethical disclosures}

Protection of human and animal subjects. The authors declare that the procedures that were followed adhered to the ethical standards of the responsible committee for experimentation on human beings and were in agreement with the World Medical Association and the Declaration of Helsinki.

Confidentiality of data. The authors declare that they followed the protocols of their work center on the publication of patient data.

Right to privacy and informed consent. The authors obtained informed consent from the patients or subjects referred to in the article. This document is in the possession of the corresponding author.

\section{References}

1. D’Hyver C. Ética y Alzheimer. Es un dilema. In: Rivero-Serrano O, editor. Reflexiones Sobre Dilemas Éticos en la Práctica Médica. Vol. 1. Mexico: Universidad Nacional Autónoma de México; 2018.
2. Brewer C. O, let me not get Alzheimer's Sweet Heaven! United Kingdom: Skycraoer Publications Limited; 2019.

3. Velázquez-López G. Síndromes demenciales. In: De la Fuente JR, Heinze G, editors. Salud Mental y Medicina Psicológica. $3^{\text {rd }}$ ed. Mexico: McGraw Hill; 2017.

4. Organización Mundial de la Salud. Switzerland: Demencia; 2019.

5. Gutiérrez-Robledo LM, Arrieta-Cruz I. Demencias en México: la necesidad de un plan de acción. Gac Med Mex. 2015;151:667-73.

6. Hernández A, Torres S. La necesidad de cuidados del paciente con Alzheimer y la respuesta social organizada. In: Gutiérrez-Robledo LM, García-Peña MC, Roa-Rojas PA, Martínez-Ruiz A, editors. La enfermedad de Alzheimer y Otras Demencias, Como Problema Nacional de Salud. Mexico: Intersistemas/Consejo Nacional de Ciencia y Tecnología; 2017.

7. Volhard T, Jessen F, Kleineidam L, Wolfsgruber S, Lanzerath D, Wagner M, et al. Advance directives for future dementia can be modified by a brief video presentation on dementia care: an experimental study. PLoS One. 2018;13:e0197229.

8. World Alzheimer Report 2019: attitudes to Dementia. Alzheimer's Disease International; 2019.

9. Reitz C. Genetic diagnosis and prognosis of Alzheimer's disease: challenges and opportunities. Expert Rev Mol Diagn. 2015;15:339-48.

10. Hickman RA, Faustin A, Wisniewski T. Alzheimer disease and its growing epidemic risk factors, biomarkers, and the urgent need for therapeutics. Neurol Clin. 2016;34:941-53.

11. Reitz C, Mayeux R. Alzheimer disease: epidemiology, diagnostic criteria, risk factors and biomarkes. Biochem Pharmacol. 2014; 88:640-51.

12. AMGEN. USA: World's Largest Alzheimer's Survey reveals most Adults Believe a Cure will be developed in their Lifetime. Thousand Oaks, California: AMGEN; 2020.

13. Piers R, Albers G, Gilissen J, de Lepeleire J, Steyaert J, van Mechelen, et al. Advance care planning in dementia: recommendations for healthcare professionals. BMC Palliat Care. 2018;17:88.

14. Steinbock B, Menzel PT. Advance directives for refusing life-sustaining treatment in dementia. Hastings Cent Report. 2018;48:S75-9.

15. González-Huerta I, Gutiérrez-Soriano J, Álvarez-del Río A. Decisiones Médicas Sobre el Final de la Vida en Pacientes con Enfermedad de Alzheimer. Mexico: Fontamara; 2017.

16. Gutiérrez-Robledo LM, García-Peña MC, Roa-Rojas PA, Martínez-Ruiz A, editors. La Enfermedad de Alzheimer y Otras Demencias, Como Problema Nacional de Salud. Mexico: Intersistemas/Consejo Nacional de Ciencia y Tecnología; 2017.

17. Detering KM, Hancock AD, Reade MC, Silvester W. The impact of advance care planning on end-of-life care in elderly patients: randomized controlled trial. BMJ. 2010;340:c1345.

18. Ying I. Artificial nutrition and hydration in advanced dementia. Can Fam Physician. 2015;61:245-8.

19. Trujillo-de los Santos Z. Cuidados paliativos. Arch Neurocytes (Mex). 2016;21:125-30.

20. Sumner LW. Physician-assisted Death. United States: Oxford University Press; 2017.

21. Volicer L. Fear of dementia. JAMDA. 2016;17:875-8.

22. Dworkin R. Life's Dominion. United States: Vintage Books; 1994.

23. Degrazia D. Advance directives, dementia, and "the someone else problem". Bioethics. 1999;13:374-91. 